\title{
ENVIRONMENTAL MANAGEMENT AS A GUARANTEE OF ENTERPRISE DEVELOPMENT
}

\section{Nataliia Skrypnyk}

Chernivtsi Institute of Trade and Economics KNTEU, Chernivtsi, Ukraine

\section{Mykola Skrypnyk}

Chernivtsi Institute of Trade and Economics KNTEU, Chernivtsi, Ukraine

\section{Serhii Rylieiev}

Chernivtsi Institute of Trade and Economics KNTEU, Chernivtsi, Ukraine

\section{OMESTE}

JEL Category: M11, Q56

\begin{abstract}
The features of the regulatory and legal support of an enterprise's environmental management are investigated. In the face of the increasing negative impact on the environment, the need to implement environmental management at enterprises becomes a top priority. Domestic environmental legislation and international organizations require intensive development of a new management tool environmental audit, which stimulates environmental protection at enterprises. This will result in increased profits, reduced costs, improved product quality and significantly reduced negative environmental impact. The distinctive features of environmental management at national and international levels have been formulated. It is proven that the system of standards in the ecology field is intended to ensure the rational use of natural resources and control of ecological safety not to forget the development of environmental programs for ecologically disadvantaged areas. The implementation of environmental management will reduce the negative impact on the environment; improve the environmental and financial performance of the enterprise; allow to develop standards for products' ecolabeling aimed at creating a single regulatory framework in this field, overcoming trade barriers. The main features and ways of development of environmental management in Ukraine are highlighted.
\end{abstract}

Keywords: standards, environmental standards, environmental management, system management, standardization and environmental policies.

Address of the corresponding author:

Nataliia Skrypnyk

z="skripnik76@ukr.net

\section{INTRODUCTION}

The current stage of development of society as a whole, and as a sphere of business activities, in particular, implies an important task of optimizing the impact of human life on the environment. 
Programs are being developed at all levels of government aimed at improving the environmental situation and reducing the negative impact of production on the environment. The ecological situation in Ukraine has long been characterized as critical. Due to structural deformations of the national economy, the most environmentally dangerous industries - raw materials and mining ones - were the most developed. A change in the industry strategy requires a change in the society, specifically in social behavior: development of new concepts of public administration and entrepreneurship, so the imbalance of natural capital use and its reproduction won't lead to large-scale destructive processes that pose a real threat to human health and social development.

In recent decades, new scientific trends have emerged, based on both classical doctrines and the latest ideas about man, society and nature, and their coexistence. One of their areas is environmental management, which offers effective tools for solving current and preventing new ecological and economic problems at production.

In the context of today's extremely difficult environmental situation in Ukraine, the study of environmental management at the enterprise becomes especially important. Environmental pollution by waste and emissions of all types of industrial production and inefficient use of resources at the enterprise increase the relevance of this problem. To prevent environmental degradation, the implementation of environmental policy at the enterprise is made. It will help improve the environment at the macro level and save resources by reducing their costs at the micro-level.

In Ukraine, there is a tendency for enterprises to reluctantly introduce an environmental management system and environmental policy because they are not able to evaluate the positive aspects of the results of such work. In our opinion, the involvement of the enterprise in its environmental policy activities will allow Ukrainian industries to increase the efficiency of environmental protection work, plan environmental measures, control compliance with environmental legislation, and reduce the likelihood of emergencies. In this regard, the application and adherence to the regulatory support of environmental management at the enterprise, even in the absence of public funds, will allow the most effective solution to the issue of environmental pollution, which is beneficial for the state as a whole and the particular enterprise in particular, regardless of the field of operation.

\section{THE ESSENCE OF ENVIRONMENTAL MANAGEMENT}

The distinctive trait of environmental management is the fact that it involves the development of environmental tasks based on appropriate strategies and programs, as well as their implementation by creating profile structures and monitoring the results at all levels. First of all, this is because environmental problems are of a lasting and global nature and affect the interests of different generations.

According to the international standard ISO 14001 , the environmental management system is a part of the general management system, which includes organizational structure, activity planning, distribution of responsibilities, practical work, as well as procedures, processes, and resources for development, implementation, evaluation of the achieved results and improvement of environmental management policy, its goals and objectives (Barkov \& Belyayeva, 2006). Therefore, environmental management can be defined as a system where those types of enterprise activities which potentially damage the environment are managed; a type of management, principally focused on the formation and development of environmental law and ecological culture of human life, which is based on socio-economic and socio-psychological motivation to achieve harmony between man and nature.

In the modern sense, environmental management studies the management relations in the enterprise, which ensure its sustainable development, environmental protection, human security, rational use of natural resources and environmental security; aims at the implementation of environmental goals and environmental impact programs, as well as an strategies for the development of society, nature management and conservation. The latter is 
determined by the biological and socio-economic characteristics of the enterprise, the strategic goals of society, and allow the organization to survive and achieve their goals in the long term.

The term "environmental management" is interpreted primarily in the following ways: activities of environmental organizations; set of activities, methods, and tools of environmental management company; system of separate natural complexes, which are subjects to special protection (Luk'yanykhin, 2002); part of the overall management system that includes organizational structure, planning, responsibilities, accountability, expertise, methods, procedures, processes, and resources to create, analyze and update environmental policy of an organization.

Environmental Management of the Enterprise is part of a general management system that includes organizational structure, planning, responsibility-sharing, practice, procedures, processes and resources that are required to develop, implement, achieve, review and adjust environmental policy goals (Siebert,1998, p. 101; Soderbaum, 2000, p. 54).

Until recently, politics and ecology were disconnected concepts. In modern politics, a new line of activity has emerged - environmental policy. The legal basis of environmental management is formed by a complex set of national and international instruments that regulate business and environmental protection intending to fulfill three main tasks: protecting and preserving the environment and maintaining its quality (water, air, land) at an adequate level; health care for employees of the enterprise and the local population; regulation of the process of consumption and use of natural resources.

\subsection{Legal and regulatory support of environmental management}

It should be noted that environmental management at the national level is governed by the State Standards of Ukraine (DSTU). In Ukraine, international standards of the ISO 14000 series were adopted in 1997, and therefore, enterprises are required to comply with them. (Pashkov, Fomin, \& Krasnyi, 1997) Thus, according to ISO 14000:2004, they must develop, implement and maintain operational procedures that must identify the potential for catastrophes or emergencies that can affect the environment. In turn, it is impossible to ignore emergencies that business entities are obliged to respond to, in particular, by mitigating the consequences or preventing their negative impact on the environment.

The regulation of environmental management at the international level is carried out using the ISO 14000 standards. The decision to develop ISO 14000 is the result of the Uruguay Round of Multilateral trade negotiations. The main subject of ISO 14000 is the environmental management system (Kupalova \& Ul'yanova, 2011, p. 51).

International environmental management standards are aimed at providing companies with elements of an effective Ecology Management System (EMS) that can be combined with other components of the enterprise's overall management system to help achieve environmental policy goals. These standards are voluntary and contain clear practical guidelines.

ISO 14000 defines various aspects of environmental management. It provides practical guidance for companies seeking to improve their environmental performance and improve the environmental situation. ISO 14001:2004 defines the basic criteria for an environmental management system that will qualify for certification. It does not set requirements as to what the environmental performance of enterprises should be but defines the areas of effective environmental management when developing environmental policies. This standard is general and universal because it can be used by any enterprise, regardless of size, scope, and industry (table 1).

According to table 1 , at the international level (unlike national) exists a mandatory element of environmental legislation - a specific set of economic instruments that serve the purpose of discouraging manufacturers from carrying out harmful or resource-intensive activities.

The main subject of ISO 14000 is the environmental management system. It helps enterprises fulfill their activities without harmful impact. 
Table 1. Regulatory support environmental management at the national and international levels

\begin{tabular}{|c|c|c|}
\hline № & Legal document & Main terms and conditions \\
\hline \multicolumn{3}{|r|}{ At the national level } \\
\hline 1 & $\begin{array}{|lr|}\text { The Law of } & \text { Ukraine } \\
\text { "Fundamentals of r the } \\
\text { Legislation of Ukraine on } \\
\text { Health Care" } & \text { from } \\
\text { 19.11.1992 №2801-XII } & \end{array}$ & $\begin{array}{l}\text { Defines legal, organizational, economic and social principles of } \\
\text { health, regulates social relations in this area }\end{array}$ \\
\hline 2 & \begin{tabular}{|l|} 
Forest Code of Ukraine from \\
21.01.1994 №3852-XII
\end{tabular} & $\begin{array}{l}\text { Regulates legal relations to provide scientifically-based management } \\
\text { of forest resources }\end{array}$ \\
\hline 3 & $\begin{array}{l}\text { The Law of Ukraine "About } \\
\text { Environmental Audit" from } \\
\text { 24.06.2004 №1862-IV }\end{array}$ & $\begin{array}{l}\text { Defines the basic legal and organizational principles of environmental } \\
\text { auditing and aims to improve the environmental feasibility and } \\
\text { effectiveness of business entities }\end{array}$ \\
\hline 4 & $\begin{array}{l}\text { Land Code of Ukraine from } \\
\text { 15.01.1993 №561-XII }\end{array}$ & $\begin{array}{l}\text { Defines the basic legal principles of land relations, objects, and } \\
\text { subjects of land relations, structure, and purpose of land, land use } \\
\text { principles }\end{array}$ \\
\hline 5 & $\begin{array}{l}\text { The Law of Ukraine "On Air } \\
\text { Protection" from 16.10.1992 } \\
\text { №2707-XII }\end{array}$ & $\begin{array}{l}\text { Defines the legal and organizational framework and environmental } \\
\text { requirements in the protection and use of air }\end{array}$ \\
\hline 6 & $\begin{array}{l}\text { Water Code of Ukraine from } \\
\text { 06.06.1995 №213/95-BP }\end{array}$ & $\begin{array}{l}\text { Regulates legal relations to scientifically substantiate rational use of } \\
\text { water for households and industries; reproduction and protection of } \\
\text { water resources }\end{array}$ \\
\hline \multicolumn{3}{|r|}{ Internationally } \\
\hline 1 & ISO 14001 & $\begin{array}{l}\text { Defines Environmental Management System (EMS), its requirements } \\
\text { and recommendations for use. Determines the model of } \\
\text { environmental management, basic terms (such as environmental } \\
\text { policy, goals and objectives, environmental management, internal } \\
\text { audit), the basic requirements for the company's environmental } \\
\text { policy, implementation and operation of environmental management }\end{array}$ \\
\hline 2 & ISO 14004 & $\begin{array}{l}\text { Defines general guidelines on principles, systems, and functioning of } \\
\text { EMS }\end{array}$ \\
\hline 3 & ISO 14010 & Defines guidelines for environmental auditing: general principles \\
\hline 4 & ISO 14011 & $\begin{array}{l}\text { Defines guidelines for environmental auditing, auditing procedures, } \\
\text { auditing environmental management systems }\end{array}$ \\
\hline 5 & ISO 14012 & \begin{tabular}{|l} 
Defines guidelines for environmental auditing, environmental \\
qualification criteria for auditors
\end{tabular} \\
\hline 6 & ISO 14014 & $\begin{array}{l}\text { Defines "entry-level" of enterprise environmental efficiency: tools of } \\
\text { environmental monitoring and evaluation }\end{array}$ \\
\hline 7 & ISO 14020 & Defines principles of ecolabeling \\
\hline 8 & ISO 14031 & $\begin{array}{l}\text { Defines manual assessment of the environmental performance of the } \\
\text { organization }\end{array}$ \\
\hline 9 & ISO 14040 & $\begin{array}{l}\text { Defines methodology of "life cycle assessment": evaluating the } \\
\text { environmental impacts associated with the products at all stages of } \\
\text { its life cycle }\end{array}$ \\
\hline 10 & ISO 14050 & Defines Environmental Management. Glossary \\
\hline 11 & ISO 14060 & $\begin{array}{l}\text { Defines manual integration of environmental aspects in standards for } \\
\text { products }\end{array}$ \\
\hline
\end{tabular}


Documents included in ISO 14000 are divided into three main groups:

- creation and use of environmental management systems;

- environmental monitoring and evaluation instruments;

- product-oriented

standards

(Maslyukovskaya, 2010).

The key concept of ISO 14000 is the Environmental Management System (EMS) of the enterprise. Therefore, the central document in this series is ISO 14001 - "Environmental management systems - Requirements with guidance for use". The series focuses on the requirement to use the "best available technology", rather than on quantitative parameters and technology. Officially, ISO 14000 standards are voluntary; they do not replace legal requirements. ISO 14000 gives guidance on how to negate the possible wrongful impacts on the environment.

Many documents in this series, implemented in Ukraine, has the term "environmental management" replaced by the term "quality management of environment", sometimes with the term "environmental administration ".

Given the major differences of the terms "environmental administration" and

"environmental management", we can offer the following definitions of both of them:

1. "Environmental Administration" - is the work of public authorities and economic agents aimed at the mandatory compliance with environmental legislation and the development and implementation of appropriate goals and programs (Burkov, Novikov, \& A.V, 2008, p. 307).

2. "Ecological Management" - a set of voluntary activities of economic entities aimed at implementing their own environmental goals, projects and programs developed based on efficiency and ecological justice. The main objectives and the corresponding criteria to assess their achievements in environmental management are related to the process of continuous improvement and perfection in all aspects of environmentally significant activities of economic entities.

\subsection{Environmental certification and its objects}

The development of practice in environmental management in Ukraine can solve various environmental problems, or at least start the job. New approaches, innovative ways, and opportunities to overcome existing negative trends in the ecological situation in the manufacturing and territorial levels can be researched.

Environmental management is linked to an already existing wide range of opportunities and tools for practical solving of priority environmental problems. Today, every enterprise has a large number of unused technological, technical and organizational capabilities and means to solve them. Thus, environmental management can play an exceptional role in solving environmental problems in the context of Ukraine's exit from the socio-economic crisis (Luk'yanykhin, 2002, p. 102).

Being international, the standards should not affect the scope of national regulations. On the other hand, the precursor of ISO is the "organizational" approach to product quality (for example, the concept of "total quality management"), according to which the key to achieving quality is to build a proper organizational structure and to share responsibility for the quality of products and services. Japan, Germany, Great Britain, and Sweden are the best when it comes to the implementation of ISO 14000 standards.

In Ukraine, the ISO 14000 standards have been adopted as national in 1997. However, the introduction is happening at a rather slow pace.

Ecological certification can be made mandatory and voluntary. Mandatory national system UkrSEPRO certifies objects, which must meet the requirements of environmental protection legislation, as so to ensure environmental safety and conservation of biological diversity. Voluntary certification may be used on other objects.

These are subject to mandatory environmental certification:

- systems of environmental management that are regulated by international standards developed by the Technical Committee ISO/TC207 «Environmental Management"; products harmful to the environment, including 
ozone-depleting substances and products containing them, which are expected to be imported to Ukraine or exported from Ukraine, as well as goods imported into the customs territory of Ukraine; environmentally harmful technologies, including those imported into the customs territory of Ukraine, which are used in industrial and research facilities and experimental enterprises;

- production and consumption waste, including hazardous and other wastes that are subject to transboundary movement; activity in the field of waste management;

- species of animals and plants, their parts or derivatives covered by the Convention on International Trade in Endangered Species of Wild Fauna and Flora, that are threatened with extinction, gathered in the high seas by Ukrainian vessels.

In the case of positive audit results, certification authorities shall grant the enterprise environmental certificates and permission to conduct ecolabeling.

Environmental management can be described as a proactive and productive number of activities done by economic entities, which aims to achieve their own environmental goals, create projects and programs developed based on environmental performance and environmental justice. This type of management is regarded as environmentally safe production management, through which an optimal balance between environmental and economic indicators is reached.

\section{THE PURPOSE AND OBJECTIVES OF ENVIRONMENTAL MANAGEMENT}

The purpose of any enterprise is to maximize profits while minimalizing operating costs. However, the process of obtaining income usually harms the environment. It is in the process of improvement of the production of goods and products nature was seized by the man in general. This problem has become acute only when society realized the need to protect the environment. The objective to reduce the negative impact on the environment is indeed the task of environmental management (Siebert, 1998, p. 198).
The main economic advantages of preventing environmental impact and environmental management are determined by the various potential benefits and additional opportunities associated with such activities, including:

- attracting investors' attention and creating additional grounds for investment benefits and privileges;

- using additional opportunities to influence consumers and increase the competitiveness of products and services produced;

- possibilities of improving the efficiency of marketing and advertising;

- attracting the attention of international organizations and the international community to the enterprise;

- using membership in international environmental unions of entrepreneurs;

- creating additional opportunities for developing relationships with business partners abroad;

- using the advantages of regional and national environmental leadership;

- with the creation of additional opportunities for development and strengthening of relations with local authorities and state ecological control, population, environmental community;

- with the creation and use of credibility in relations with investors, shareholders, local authorities and state environmental control, population, environmental public;

- with the creation of additional opportunities for strengthening and expanding positions on international commodity and financial markets (Soderbaum, 2000, p. 321).

Thus, the effective activity of the enterprise in the field of environmental management is considered as the main guarantee of environmental safety and the ability to manage environmental risks in the process of design and operation of facilities.

\subsection{Implementation of an environmental management system at the enterprise}

According to many scientists, the main goals of implementing the enterprise environmental management system and its certification include: 
- reducing the negative impact on the environment;

- improving the environmental performance of the enterprise;

- improving the economic efficiency of the enterprise.

In developed countries, environmental certification is quite common, it is mandatory, and complements product and service certification. Due to the competition of ecological certification marks, in which individual sellers do not always follow the established rules, a special ISO Subcommittee on Eco-labeling of Products was created. The ecological certification is based on the requirements of ISO 14000 standards and was concluded in 1999 by the Agreement of Ten European Countries on the Mutual Recognition of Accreditation of Environmental Certification Bodies, Testing Laboratories, Certification of Inspection Bodies and Personnel. Thus, ecological certification of products (services) is carried out to stimulate the production of products, provide services and use technological processes that least pollute the environment and guarantee the safety of products (services) for life, health, property, and the environment. This necessitates ecological certification for all civilized countries (Kupalova \& Ul'yanova, 2011).

Environmental management was created in advanced market economies to achieve parity between the economic interests of the producer and the environmental and social needs of society.

The main features of environmental management are (Zagorodniuk, 2014, p. 9):

- it is part of the overall environmental management system;

- it is a market-based environmental management system;

- its effect is limited at the territorial hierarchical level within the region, corporation, enterprises in the areas with market relations, and first of all, production.

The enterprise is the first and most important element that influences pollution and where the environmental gradation in human economic activity. Environmental management is closely linked to the enterprise strategy. The strategy of the modern enterprise is to achieve the necessary rates of economic development, increase in production volumes, profit in the conditions of fierce competition in foreign and domestic markets.

Features of environmental management of the enterprise are an organizational structure that provides environmental management at the enterprise; environmental policy of the enterprise; financing of environmental measures; industrial environmental monitoring; dissemination of environmental information.

The lack of an effective environmental management system and slow implementation of structural reforms and modernization of technological processes in the context of national economic growth lead to increased pollution. And these as follows support old, inefficient approaches to the use of energy and natural resources. The crucial role in the implementation of the environmental management system at enterprises is played by an environmental audit, which provides for a comprehensive environmental audit of the production system, financial activities, and compliance. The recommendations of the initial environmental audit of the enterprise are decisive for the implementation of all subsequent stages of implementation of the environmental management system and the content of specialized internal environmental documents: programs for the design and implementation of environmental management, guidelines from the environmental management system, internal environmental regulations of the company, etc. (Smolens'kyy, 2014, p. 75).

Attempts to create universal, binding, environmental regulations for economic activity in all the countries will be doomed to failure until the widening gap between poverty and wealth, basic socio-economic problems in developed and developing countries with a transition economy are resolved in the world, a favorable regime for access to goods on world markets are created, and effective mechanisms for financing development are developed. 


\subsection{Restoration of ecological balance due to the implementation of effective legal regulation}

The environmental management system is often defined as a system of planning, organization, implementation, and control over the activities of the enterprise, aimed at achieving environmental goals and its long-term stable operation as a whole (Soderbaum, 2000, p. 99). Such a system implements environmentally-friendly activities that permeate all the functions of the enterprise. However, its main disadvantage is that it does not provide opportunities for creation, development, change of means and conditions for achieving the environmental goals of the enterprise, and assumes the use of only its available funds But it is known that priority is often given to economic goals, and environmental and environmental objectives are included in the overall plan of the enterprise to implement legislative regulations or through fierce competition.

Ukraine entered the top five European countries by the number of deaths caused by environmental pollution. This was reported by the Global Alliance for Health and Pollution (GAHP). According to research, 57,258 people die each year due to environmental pollution (Total Pollution Deaths) in Ukraine. Based on this number, Ukraine ranks fourth among European countries. The top three leaders in the region include Turkey $(57,779$ deaths), Germany $(68,300)$ and the Russian Federation $(118,687)$.

Table 2. Top 5 European Countries by Deaths from Pollution in 2017 (Fuller, Sandilya, \& Hanrahan, 2019)

\begin{tabular}{|l|l|c|}
\hline № & \multicolumn{1}{|c|}{ Country } & $\begin{array}{c}\text { Total Pollution } \\
\text { Deaths }\end{array}$ \\
\hline 1. & $\begin{array}{l}\text { Russian } \\
\text { Federation }\end{array}$ & 118687 \\
\hline 2. & Germany & 68300 \\
\hline 3. & Turkey & 57779 \\
\hline 4. & Ukraine & 57258 \\
\hline 5. & Italy & 57033 \\
\hline
\end{tabular}

Also, Ukraine ranks fourth place in the number of deaths due to environmental pollution per 100 thousand people (Pollution Deaths per 100,000 population). Leading are Bulgaria (137), Georgia (140) and Serbia (175).
Table 3. Top 5 European Countries by Deaths from Pollution per 100,000 Population in 2017 (Fuller, Sandilya, \& Hanrahan, 2019)

\begin{tabular}{|l|l|c|}
\hline № & \multicolumn{1}{|c|}{ Country } & $\begin{array}{c}\text { Pollution Deaths per } \\
\mathbf{1 0 0 , 0 0 0} \text { population }\end{array}$ \\
\hline 1 & Serbia & 175 \\
\hline 2 & Georgia & 140 \\
\hline 3 & Bulgaria & 137 \\
\hline 4 & Ukraine and & 128 \\
\hline 5 & $\begin{array}{l}\text { Bosnia andia } \\
\text { Herzegovina }\end{array}$ & 125 \\
\hline
\end{tabular}

The Alliance stated that India $(2,326,771)$, China $(1,865,566)$, Nigeria $(279,318)$, Indonesia $(232,974)$, Pakistan $(223,836)$, Bangladesh $(207,922)$ and United States $(196,930)$ are the leaders in the number of premature deaths in the world due to environmental problems.

According to the State Statistics Service of Ukraine, emission density from stationary sources of pollution per 1 square $\mathrm{km}$ of the country's territory averaged 4.35 tons of harmful substances in 2018 (per capita - $59.3 \mathrm{~kg}$ ). However, in some regions, these figures far exceeded the average in Ukraine. In particular, in Donetsk region emissions per 1 square $\mathrm{km}$ was 6.9 times bigger (per capita bigger by 2.1 times), in Dnipropetrovsk - by 4.4 and 3.2 times respectively, in Ivano-Frankivsk 3.7 and 2.7 times. Enterprises of Kyiv have produced 35 tons of pollutants per 1 square $\mathrm{km}$ into the atmosphere, which exceeded the national average by 8 times. (Official site of the State Statistics Service of Ukraine)

It should be noted that in the face of exacerbation of the ecological crisis in the world, it is extremely important to find ways to restore the ecological balance through the introduction of effective legal regulation. The main trends that characterize the state of environmental safety show that two-thirds of harmful substances get into the air from stationary sources of pollution of industrial enterprises, whose environmental activities are not regulated by clear regulatory documents. At the state level, environmental policy should identify the main tools and levers of environmental impact. They must be both administrative and market-based. Nowadays in Ukraine, the environmental status is regulated through standardization and environmental regulation. At the same time, if the standards are clear and binding, then the rules established in 
environmental activities determine the maximum permissible limits of the impact of the enterprise on the environment in which it must operate. Such rules and regulations are intended to assist enterprises in the development of production capacities, taking into account the established values of certain environmental impact factors (for example, emissions into the atmosphere, mining, waste management, etc.).

Important sources of development of legal and regulatory issues for environmental management in Ukraine would be such components as economic and environmental regulation, environmental audit and environmental licensing. Economic and environmental regulation is the establishment of boundaries within which the development of production and changes in the natural properties of the natural environment are allowed. It should be noted that in Ukraine this element is characterized by a large number of regulations that are either declarative or radically different, and sometimes contradictory. According to current legislation, environmental regulations include environmental safety standards and the maximum permissible levels of emissions and discharges into the environment. Environmental standards are developed and implemented by the Ministry of Ecology and Natural Resources of Ukraine.

The need for environmental audits is related to the lack of reliable information on the negative environmental impact of economic entities. An environmental audit is a documented systematic independent process for evaluating an environmental audit entity. It includes the collection and objective evaluation of evidence to determine the compliance of certain activities, measures, conditions, environmental management systems and information on these issues with the requirements of the legislation of Ukraine on environmental protection and other criteria of environmental audit.

Environmental licensing sets environmental requirements and restrictions in the form of a special permit to conduct specific economic or other activities of environmental users in the relevant territory (facility).In Ukraine, environmental licensing involves the granting of a permit (license) for the implementation of a certain type of environmental activity.

\section{CONCLUSIONS}

The study results indicate a low level of implementation of the environmental management system according to ISO 14001 in the activity of Ukrainian enterprises. The regulatory support for environmental management is broad enough to cover international and national levels. However, there are many inconsistencies and declarations in the current legislation of Ukraine that need to be eliminated or specified to achieve the goals of the state's environmental policy. Also, the development of environmental management is constrained by a lack of financial resources. In such circumstances, government regulation in addition to administrative methods, such as mandatory standardization, should include market-based tools to encourage businesses. The implementation of environmental management into the practice of enterprise management will affect the improvement of ecological and economic management of it, contribute to the stabilization and development of the Ukrainian industry. The realization of the state strategy of sustainable development of the country and its regions implies a set of measures for state regulation of nature management and stimulation of environmental protection activities through the implementation of purposeful ecological and economic policy in the conditions of market relations.

Thus, the system of standards in the field of ecology is supposed to:

- ensure the implementation of the system of environmental legislation. the main directions of the state policy in the field of environmental protection, use of natural resources and control of ecological safety are determined based on these activities, not to forget nature protection programs for ecologically disadvantaged areas;

- manage the sustainable development of ecolabeling standards aimed at creating a single regulatory framework in the field and help to overcome trade barriers;

- to systematize the methods of ecological certification, which will lead to the stabilization of environmental policy and the creation of an economic and legal mechanism for the realization of the citizens right enshrined in the Constitution to a favorable environment. 
- $\quad$ support the sustainable development of ecolabeling standards aimed at creating a single regulatory framework in the field and help to overcome trade barriers; systematization of environmental certification will lead to stabilization of environmental policy and the creation of an economic and legal framework for the implementation embodied in the
Constitution the right of citizens to a healthy environment.

- systematization of environmental certification will lead to the stabilization of environmental policy and the creation of an economic and legal framework for the implementation embodied in the Constitution the right of citizens to a healthy environment.

\section{WORKS CITED}

Barkov, D., \& Belyayeva, Y. (2006, 08 26). Mezhdunarodnyye ekologicheskiye standarty kachestva produktsii ISO14000 i perspektivy ikh vnedreniya v Ukraine. Retrieved from ecologylife.ru: http://www.ecologylife.ru/odesski-region/mezhdunarodnyie-ekologicheskie-standartyikachestva-produktsii-iso14000-i-perspektivyi-ih-vnedreniya-v-ukraine.html

Burkov, V., Novikov, D., \& A.V, S. (2008). Mekhanizmy upravleniya ekologo-ekonomicheskimi sistemami. Moscow: Fizmatlit.

Fuller, R., Sandilya, \& Hanrahan, D. (2019, 12). Pollution and health metrics. Retrieved from GAPH Global, Regional, and Country Analysis: http://gahp.net/wpcontent/uploads/2019/12/PollutionandHealthMetrics-final-12_18_2019.pdf

Kupalova, G., \& Ul'yanova, D. (2011). Formation of an efficient system of ecological management and audit. Bull. of Univ. of Banking of NBU, 1(11), 48-53.

Luk'yanykhin, V. (2002). Ekologichnyi menedzhment u systemi upravlinnya zbalansovanym rozvytkom. Sumy: Univer. Knyga.

Maslyukovskaya, E. (2010). Pakety instrumentov ekologicheskogo regulirovaniya. In L. Mel'nik, \& E. Shkarupa, Metody Resheniya Ekologicheskikh Problem (pp. 153-164). Sumy: Sumy State University.

Pashkov, E., Fomin, G., \& Krasnyi, D. (1997). Mezhdunarodnye Standarty ISO 14000. Moscow: Izdat. Standartov.

Siebert, H. (1998). Economics of Environmental Theory and Policy. Berlin: Springer.

Smolens'kyy, I. (2014). Systema ekolohichnoho menedzhmentu v pidpryyemstvi. Ekonomika Ukrayiny(12), 73-80.

Soderbaum, P. (2000). Ecological Economics: A Political Economics Approach to Environment and Development. London: Earthscan.

Zagorodniuk, P. (2014). The relationship between ecological and economic security and its impact on the economic growth of Ukraine. Environmental Ecology and Life Safety(6), 9-14.

Received for publication: $\quad 26.12 .2019$

Revision received: $\quad 04.01 .2020$

Accepted for publication: $\quad 10.01 .2020$

\section{How to cite this article?}

Style - APA Sixth Edition:

Skrypnyk, N., Skrypnyk, M., \& Rylieiev, S. (2020, January 15). Environmental management as a guarantee of enterprise development. (Z. Cekerevac, Ed.) MEST Journal, 8(1), 111-121. doi:10.12709/mest.08.08.01.13 
Style - Chicago Sixteenth Edition:

Skrypnyk, Nataliia, Mykola Skrypnyk, and Serhii Rylieiev. 2020. "Environmental management as a guarantee of enterprise development." Edited by Zoran Cekerevac. MEST Journal (MESTE) 8 (1): 111-121. doi:10.12709/mest.08.08.01.13.

Style - GOST Name Sort:

Skrypnyk Nataliia, Skrypnyk Mykola and Rylieiev Serhii Environmental management as a guarantee of enterprise development [Journal] // MEST Journal / ed. Cekerevac Zoran. - Belgrade - Toronto : MESTE, January 15, 2020. - 1 : Vol. 8. - pp. 111-121.

Style - Harvard Anglia:

Skrypnyk, N., Skrypnyk, M. \& Rylieiev, S., 2020. Environmental management as a guarantee of enterprise development. MEST Journal, 15 January, 8(1), pp. 111-121.

Style - ISO 690 Numerical Reference:

Environmental management as a guarantee of enterprise development. Skrypnyk, Nataliia, Skrypnyk, Mykola and Rylieiev, Serhii. [ed.] Zoran Cekerevac. 1, Belgrade - Toronto : MESTE, January 15, 2020, MEST Journal, Vol. 8, pp. 111-121. 